\title{
PREVALENCE AND CD4 CELL COUNT PATTERN OF TB CO- INFECTION AMONG HIV INFECTED INDIVIDUALS IN NEPAL
}

\author{
Niraula SR, Barnawal SP, Agrahari AK, Bista N, Yadav DK, Jha N, Pokharel PK \\ School of Public Health and Community Medicine, B. P. Koirala Institute of Health Sciences, Dharan, \\ Nepal
}

\begin{abstract}
Background: Mycobacterium tuberculosis (TB) and Human Immunodeficiency Virus (HIV) infections are two major public health problems in many parts of the world, particularly in developing counties like Nepal. The objective of the study is to find out prevalence and clinical presentation of the TB co-infection among HIV infected individuals and pattern of CD4 cell count in relation to types of TB and response of ART.

Methodology: This is a cross-sectional study carried out in three VCT clinics from Dharan and Kathmandu from April 2010 to March 2011. The appropriate samples, 313 HIV individuals were taken as study sample.

Results: The study revealed that more than $36 \%$ of individuals were co-infected with TB. Among them, nearly $65 \%$ had pulmonary TB, more than one-forth had gland TB. There is significant association of TB co-infection among male compared to females $(P=0.021)$. Fever, weight loss and cough were found to have significant symptoms associated with TB-HIV co-infection. The average CD4 count among TB co-infected population was significantly less compared to uninfected ones just before starting ART $(P=0.022)$ and even after six months $(P=0.001)$. After one year of $A R T$ continuation, there was no significant association on average CD4 count among the two groups. But then, the mean CD4 count became more in TB co-infected individuals compared to those who had no TB co-infection.

Conclusion: TB-HIV co-infection is an emerging medical issue in Nepal. More than one third of HIV patients are co-infected with TB. Consideration of TB need to be made while caring patients with HIV infection and vice versa. ART plays very important role in increasing $\mathrm{CD}_{4}$ cell count among TB-HIV coinfected patients.
\end{abstract}

Key words: HIV, TB co-infection, CD4 cell count, Clinical features, ART

\section{INTRODUCTION}

The United Nations Joint Programme on HIVIAIDS (UNAIDS, 2009) report estimated that 33.4 million people are living with Human Immunodeficiency

\section{Correspondence:}

Dr. Surya Raj Niraula

Additional Professor

School of Public Health and Community Medicine

B P Koirala Institute of Health Sciences, Dharan,

Sunsari, Nepal

E-mail: sniraula@uw.edu or sniraula@yahoo.com
Virus (HIV) in worldwide, and one third of them are co-infected with tuberculosis (TB). HIV infection increases susceptibility to TB and is the most potent factor in transferring latent or recently acquired TB infection to active clinical diseases. In addition, TB in high HIV prevalence populations is a leading cause of morbidity and mortality. TB patients have been suggested to be an important population for finding of HIV infections. Therefore, prevention and control of co-infection is vital to reduce the epidemic of TB and HIVI AIDS. ${ }^{1}$

An estimated 2 million deaths have been attributed annually to HIVIAIDS, with approximately 250,000 
pediatric deaths. ${ }^{2}$ In infants and young children, immune system immaturity and high viral loads lead to a high risk of rapid disease progression. ${ }^{3}$

Since the detection of the first AIDS case in 1988, the HIV epidemic in Nepal has evolved from a low prevalence to concentrated epidemic. As of 2009, national estimates indicate that approximately 63,528 adults and children are infected with the HIV virus in Nepal, with an estimated prevalence of about $0.39 \%$ in the adult population. ${ }^{4}$

Mycobacterium tuberculosis and human immune deficiency virus infections are two major public health problems in many parts of the world, particularly in many developing counties. ${ }^{1}$ Coinfection with HIV may worsen the course and complicate the diagnosis and management of TB. Overall, HIV-infected patients have $60 \%$ higher risk of acquiring TB in comparison to $10 \%$ in non HIV group and this risk remains elevated throughout the course of HIV disease. ${ }^{5}$ Prompt diagnosis and treatment are essential to improve drug-resistant TB outcomes, but TB diagnosis in patients with HIV co-infection is challenging, particularly in resource-limited settings. HIV-infected TB patients have higher rates of extra-pulmonary disease, atypical clinical presentations, and normal chest radiographs. ${ }^{6}$

Tuberculosis and HIV control programmes clearly have mutual concerns: the prevention of HIV infection and the treatment of HIVIAIDS should be components of tuberculosis control, and tuberculosis care and prevention should be priorities in the management of HIVIAIDS. ${ }^{7}$ TB is the most frequent life-threatening opportunistic disease among people living with HIV and remains a leading cause of mortality, even among persons receiving antiretroviral therapy (ART). Clinical trials have shown that isoniazid preventive therapy (IPT) dramatically reduces the incidence of TB among people living with HIV. A 2004 Cochrane Review found that IPT reduced the risk of TB by $33 \%$ overall and by $64 \%$ when targeted to people living with HIV who had a positive tuberculin skin test. A recent retrospective study also showed that IPT significantly reduced the incidence of TB even among people living with HIV and receiving ART. ${ }^{8}$

CD4 $T$ cells are critical in the control of $M$. tuberculosis infection, as quantitative and qualitative deficiencies of these effecter cells in
HIV-infected individuals increase the rates of both primary and reactivation disease. While the lifetime risk of developing active TB is approximately $10 \%$ for immune-competent persons following initial infection, for persons with HIV co-infection the annual risk can exceed $10 \%$, and the risk of TB reactivation rises as the $\mathrm{CD} 4$ cell count declines. ${ }^{2}$ HIV-infected persons are at risk of TB throughout their course of disease, even after they respond to ART. $^{9}$

In Nepal, the first case was demonstrated in 1988 and the concept of treating HIV infection with highly active antiretroviral treatment (HAART) was introduced quite later. ${ }^{10}$ Among those with HIV infection, the CD4+ T-lymphocyte count is the major indicator of immunodeficiency, a main factor in deciding whether to initiate HAART, and an important parameter in monitoring treatment response. Despite current recommendations to start HAART at CD4+ counts of 350 cells $/ \mathrm{mm} 3$ or greater, the reality is that many patients, even in developed countries, are still being diagnosed and initiate treatment late in the course of their HIV infection. ${ }^{11}$

Treatment of tuberculosis patients in resourcelimited countries with concurrent epidemics of Hepatitis C Virus (HCV), Hepatitis B Virus (HBV), and HIV may be associated with significant hepatoxicity. Serologic screening of tuberculosis patients for HBV, HCV and HIV or using behavioral algorithms to identify patients in need of intensive monitoring during anti-tuberculosis therapy may reduce this risk. ${ }^{12}$

The present study is focused to find out prevalence of TB among HIV infected individuals, clinical features and $A R T$ response on $C_{4}$ cell count.

\section{METHODOLOGY}

Setting: The study was carried out in three different places viz. BPKIHS, Dharan; SPARSA Nepal, Kathmandu and Sukhra Raj Tropical and Infectious Disease Hospital, Teku, Kathmandu (TEKU Hospital) from April 2010 to March 2011. It was done with due privacy in their respective VCT Clinic by face to face interview with the HIV infected individuals based on pretested semistructured questionnaire. Also, an address was given to the past medical documents, for better 
authenticity of the information, which most of them had themselves.

Study subjects: The target population of the study was the HIV infected persons visiting the VCT Clinic either for taking medications or for follow-up of regular check up during 1 year period. Among those who gave supportive consent, an approach was made to include all individuals whether they were already taking medications or about to start. A total of 313 HIV infected individuals were interviewed.

Study design and sample size: This is a cross sectional, descriptive study which includes primary and secondary data. Based on the prevalence of TB co-infection among HIV individuals (33.3\%)1, the required sample size was calculated as 315 based on the precision of 5.33 ( $16 \%$ of prevalence) at $95 \%$ confidence limit after adding $5 \%$ for nonresponse. Two individuals disagreed to participate in the study.

Exclusion criteria: Those who didn't give consent and who couldn't report $\mathrm{CD}_{4}$ count were excluded. The $\mathrm{CD}_{4}$ count was done by the patients themselves.

Statistical analysis: The data was entered into Microsoft Excel 2007 and analyzed in SPSS 17.0. Mean, median and standard deviation were calculated. Mann-Whitney Test and Chi square test were applied to find out statistical significance in numeric and categorical data respectively. Probability of significance was set at $5 \%$ level of significance. Odds Ratio (OR) and its 95\% confidence interval $(\mathrm{Cl})$ were also calculated to examine strength of association between the categorical variables and its' limit.

Ethical consideration: Ethical consent was taken from institutional review board BPKIHS, Dharan; SPARSA NEPAL, Kathmandu and Sukhra Raj Tropical and Infectious Disease Hospital (Teku, Kathmandu). Verbal consent was also taken with the individuals who were diagnosed to be HIV infected prior to interview. Privacy of participants was maintained during interview with due consideration of the emotional aspect.

The normal oral or ear temperature is $37^{\circ} \mathrm{C}$ but may range between $35.8^{\circ} \mathrm{C}$ and $37.2^{\circ} \mathrm{C} .{ }^{13}$ The temperature more than this was considered to be fever. Diarrhea was defined as 2 or more loose or watery stools per day for more than 2 consecutive days. ${ }^{14}$ Chronic diarrhea was defined as diarrhea persisting for more than 14 days. ${ }^{15}$ Tuberculosis coinfection was ascertained by past medical records and history of taking anti-tubercular therapy. HBV and HCV infection were considered positive with respect to serological tests as per medical records. Individuals who gave history of use of syringes for self administration of drugs were considered intravenous drug users (IDU). Most of IDU, but not all, had multiple scar marks on their forearm. The threshold for starting ART was considered to be $\mathrm{CD}_{4}$ count to be less than $250 / \mu \mathrm{L}$. Weight loss may be due to lack of food intake (anorexia, dysphasia or vomiting), mal-absorption of nutrients, or a systemic effect of important diseases such as cancer (within or outside the gastrointestinal tract), inflammatory bowel disease or chronic infections such as TB (within or outside the gastrointestinal tract). ${ }^{16}$ Weight loss in HIV infected patients can be due to HIV wasting syndrome or due to chronic infections like tuberculosis. HIV wasting syndrome has been defined by the Centre for Disease Control (CDC), USA, as involuntary weight loss greater than $10 \%$ of baseline weight associated with either chronic diarrhea for at least 30 days or chronic weakness or documented fever for at least 30 days in the absence of a concurrent illness or condition other than HIV infection that could explain findings (e.g., tuberculosis, cryptosporidiosis, or other specific enteritis). ${ }^{17}$ We were mainly focused on weight loss due to tuberculosis.

\section{RESULTS}

The mean age of the individuals was 33.7 years which ranged from 2 years to 67 years. Around one-third were males. Almost $40 \%$ of males and $25.3 \%$ of females had TB co-infection. In the study sample, $72.8 \%$ were married, $8 \%$ were unmarried, $14.1 \%$ were single, $5.1 \%$ was widow/widower. Of the total sample $65.5 \%$ were IDU and $34.5 \%$ were non-IDU. Majority of them (94.2\%) were receiving ART and $5.8 \%$ were to start ART or not taking ART. The study revealed that $36.1 \%$ persons were coinfected with tuberculosis. About $5.75 \%$ had HBV and $41.53 \%$ had HCV infection (Table 1).

There was significant association of TB coinfection among male compared to females 


\begin{tabular}{|c|c|c|c|}
\hline \multicolumn{2}{|c|}{ Variables } & Frequency & $\%$ \\
\hline \multirow[t]{2}{*}{ Sex } & Male & 234 & 74.8 \\
\hline & Female & 79 & 25.2 \\
\hline \multirow[t]{5}{*}{ Marital Status } & Married & 228 & 72.8 \\
\hline & Unmarried & 25 & 08.0 \\
\hline & Single & 44 & 14.1 \\
\hline & Widow & 6 & 01.9 \\
\hline & Widower & 10 & 03.2 \\
\hline \multirow{4}{*}{$\begin{array}{l}\text { Living with (for } \\
\text { consideration of } \\
\text { social support) }\end{array}$} & Family & 193 & 61.7 \\
\hline & $\begin{array}{l}\text { Rehabilitation } \\
\text { center }\end{array}$ & 67 & 21.4 \\
\hline & Alone & 51 & 16.3 \\
\hline & Friends & 2 & 00.6 \\
\hline \multirow[t]{5}{*}{$\begin{array}{l}\text { Reason for First } \\
\text { Recognition } \\
\text { of Having } \\
\text { acquired HIV } \\
\text { Infection }\end{array}$} & \begin{tabular}{|l|} 
Increased \\
Severity of \\
Presenting \\
Illness \\
\end{tabular} & 180 & 57.5 \\
\hline & \begin{tabular}{|l|} 
Accidental \\
Examination of \\
Blood
\end{tabular} & 65 & 20.8 \\
\hline & $\begin{array}{l}\text { Spouse Being } \\
\text { HIV positive }\end{array}$ & 49 & 15.6 \\
\hline & $\begin{array}{l}\text { Deliberate } \\
\text { Checkup for } \\
\text { HIV }\end{array}$ & 12 & 03.8 \\
\hline & \begin{tabular}{|l} 
Presence \\
of Risk \\
Behavior(s) \\
\end{tabular} & 7 & 02.2 \\
\hline \multirow[t]{2}{*}{ TB Co-infection } & Yes & 113 & 36.1 \\
\hline & No & 200 & 63.9 \\
\hline \multirow[t]{2}{*}{ IDU } & Yes & 205 & 65.5 \\
\hline & No & 108 & 34.5 \\
\hline \multirow[t]{2}{*}{ ART } & Being Taken & 295 & 94.2 \\
\hline & $\begin{array}{l}\text { Not Being } \\
\text { Taken }\end{array}$ & 18 & 05.8 \\
\hline \multirow{2}{*}{$\begin{array}{l}\text { Hepatitis } \\
\text { Co-infection }\end{array}$} & HBV & 18 & 5.75 \\
\hline & $\mathrm{HCV}$ & 130 & 41.503 .0 \\
\hline \multirow{3}{*}{$\begin{array}{l}\text { VCT Centers } \\
\text { Visited }\end{array}$} & BPKIHS & 65 & 20.8 \\
\hline & SPARSA Nepal & 95 & 30.4 \\
\hline & $\begin{array}{l}\text { TEKU } \\
\text { HOSPITAL }\end{array}$ & 153 & 48.9 \\
\hline
\end{tabular}

$(\mathrm{OR}=1.95, \mathrm{Cl}=1.06-2.37, \mathrm{P}=0.021)$. Regarding the clinical feature of HIV individuals, $53.8 \%$ had fever, $46.5 \%$ experienced weight loss, $41 \%$ suffered from chronic diarrhea, $37.2 \%$ had cough, $34.4 \%$ had rashes, $28.5 \%$ had headache, $23.6 \%$ used to get fatigue easily, $12.8 \%$ had oral lesions, $7.6 \%$ had blurred vision, $3.8 \%$ genital lesions and $2.8 \%$ had night sweats (Table 2). Around two third had pulmonary TB, $25.7 \%$ had gland TB, $5.3 \%$ had spinal TB, $2.7 \%$ had abdominal TB and $1.8 \%$ had tuberculosis of Meninges (Figure 1).

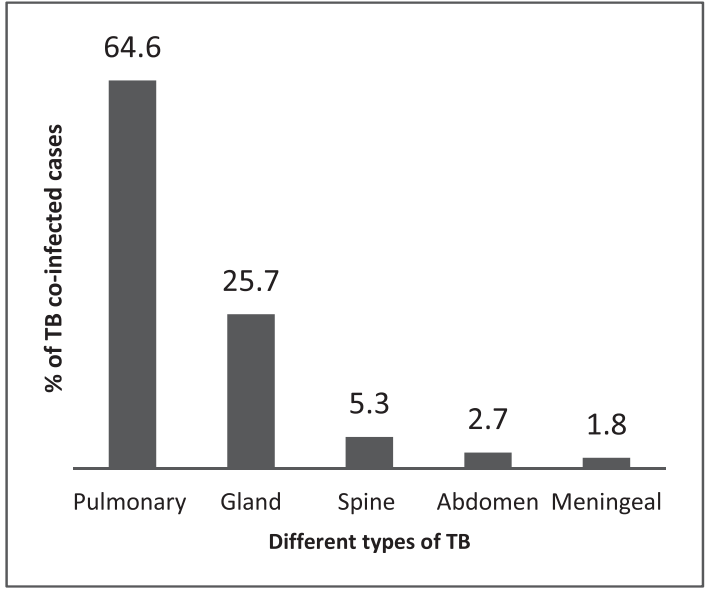

Figure 1. Different types of TB co-infection (\%) among HIV positive individuals in three VCT centers. $(n=113)$.

But among TB co-infected ones the presenting clinical features were quite different. Around $83 \%$ had fever, $69 \%$ experienced weight loss, $59.3 \%$ had cough, $31 \%$ suffered from chronic diarrhea, $29.2 \%$ had headache, $21.2 \%$ used to get fatigue easily, and $4.4 \%$ had night sweats (Figure 2.)

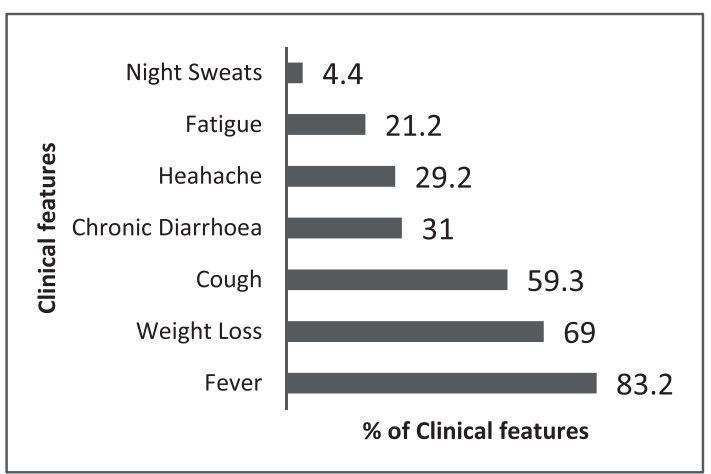

Figure 2. Clinical presentation HIV infected individuals co-infected with of TB in three VCT centers. $(n=113)$.

Fever was found to be significantly associated with TB co-infection (OR=11.27, Cl=6.11-20.99, $\mathrm{P}<0.001$ ). Weight loss was also found to be significantly associated with TB co-infection $(\mathrm{OR}=5.73, \quad \mathrm{Cl}=3.36-9.81, \quad \mathrm{P}<0.001)$. Similarly, cough had significant relation with TB co-infection (OR=5.83, $\mathrm{Cl}=3.39-10.05, \mathrm{P}<0.001$ ) (Table 2.).

Table 3 shows the average CD4 count among those individuals who had TB co-infection was found to be significantly less compared to the individuals who didn't have TB co-infection in case of just before starting ART $(P=0.022)$. Similarly, after six months, the mean $C D_{4}$ count was significantly 
associated among them $(P=0.001)$. But after one year of starting ART, there was no significant association on average CD4 count among the two groups. However, data shows a slight increment in average CD4 count among TB co-infected persons than not infected persons. Similar association was observed after 1.5 years, 2 years, 2.5 years, 3 years and 3.5 years.

Table 4 demonstrates those population who were taking ART, had mean CD4 count of 180.16 $(S D=98.97$ and median $C D 4$ count $=168)$ just before starting ART compared to mean $\mathrm{CD} 4$ count of 447.78 ( $\mathrm{SD}=166.05$ and median $=425)$ in the individuals who were not taking ART. Mean CD4 count was in increasing pattern without any decline for two and half years among the population taking ART. But in succeeding six months' duration, the mean CD4 count decreased to 379.39 (SD $=147.69$ and median $=376.5)$. In subsequent six month the mean CD4 count increased to 410.28 (SD=168.47 and median CD4 count=376.5). The mass not taking ART had falling pattern of mean CD4 count for one and half year.

Table 2. Clinical features in HIV infected people along with tuberculosis co-infection. $(n=113)$

\begin{tabular}{|c|c|c|c|c|c|c|c|}
\hline \multicolumn{2}{|c|}{$\begin{array}{c}\text { Variables } \\
\text { Yes(n=113)\% }\end{array}$} & \multicolumn{2}{|c|}{$\begin{array}{l}\text { Presence of TB } \\
\text { Co-infection }\end{array}$} & \multirow{3}{*}{$\begin{array}{c}\begin{array}{c}\text { Total } \\
(\mathrm{n}=313)\end{array} \\
155\end{array}$} & \multirow{3}{*}{$\begin{array}{c}\mathrm{OR}(\mathrm{Cl}) \\
11.27(6.11-20.99)\end{array}$} & \multirow{3}{*}{$\begin{array}{l}X^{2} \text { value } \\
80.18 \\
\end{array}$} & \multirow{3}{*}{$\begin{array}{l}\text { P value } \\
<0.001 \\
\end{array}$} \\
\hline & & \multirow{2}{*}{$\begin{array}{c}\mathrm{No}(\mathrm{n}=200) \% \\
83.2 \\
\end{array}$} & \multirow[b]{2}{*}{34.9} & & & & \\
\hline \multirow{7}{*}{$\begin{array}{l}\text { Clinical } \\
\text { features }\end{array}$} & Fever & & & & & & \\
\hline & Weight loss & 69.0 & 32.0 & 134 & $5.73(3.36-9.81)$ & 49.64 & $<0.001$ \\
\hline & Cough & 59.3 & 22.9 & 107 & $5.83(3.39-10.05)$ & 49.55 & $<0.001$ \\
\hline & Chronic diarrhea & 31.0 & 47.4 & 118 & $0.63(0.38-1.06)$ & 3.41 & NS \\
\hline & Headache & 29.2 & 28.0 & 82 & $1.27(0.73-2.20)$ & 0.83 & NS \\
\hline & Fatigue & 21.2 & 25.1 & 68 & $0.96(0.52-1.74)$ & 0.02 & NS \\
\hline & Night sweats & 4.4 & 1.7 & 8 & $3.04(0.62-16.39)$ & 1.44 & NS \\
\hline \multirow[t]{2}{*}{ Sex } & Male & 39.7 & 60.3 & & \multirow[t]{2}{*}{$1.95(1.06-2.37)$} & \multirow[t]{2}{*}{5.329} & \multirow[t]{2}{*}{0.021} \\
\hline & Female & 25.3 & 74.7 & & & & \\
\hline
\end{tabular}

Table 3. Change and comparison of $\mathrm{CD}_{4}$ cell count in HIV infected persons six monthly, among those who had TB co-infection and those who hadn't, during the course of ART for three and half years. $(n=313)$

\begin{tabular}{|c|c|c|c|c|}
\hline \multirow{2}{*}{$\begin{array}{c}\text { CD4 Count } \\
\text { (Six Monthly ) }\end{array}$} & \multicolumn{2}{|c|}{ Presence of TB Co-infection } & \multirow[t]{2}{*}{ Total } & \multirow[t]{2}{*}{$P$ value } \\
\hline & Yes & No & & \\
\hline $\begin{array}{l}\text { Just Before Starting ART } \\
\text { (Mean } \pm \text { SD), Median, No. }\end{array}$ & $(171.65 \pm 101.48), 161.00,113$ & (209.05 \pm 128.95$), 182.00,200$ & $(195.55 \pm 120.94), 172.00,313$ & $0.022^{*}$ \\
\hline $\begin{array}{l}\text { At } 6 \text { Months' Duration } \\
\text { (Mean } \pm \text { SD), Median, No. }\end{array}$ & $(251.42 \pm 141.59), 221.00,106$ & (281.94 \pm 106.63$), 268.00,184$ & $(270.79 \pm 121.27), 255.50,290$ & $0.001^{*}$ \\
\hline $\begin{array}{l}\text { At } 1 \text { Year's Duration } \\
\text { (Mean } \pm \text { SD), Median, No. }\end{array}$ & ${ }^{* *}(311.87 \pm 180.88), 283.00,87$ & $(297.61 \pm 116.67), 304.00,142$ & $(303.03 \pm 144.24), 293.00,229$ & 0.576 \\
\hline $\begin{array}{l}\text { At } 1.5 \text { Years' Duration } \\
\text { (Mean } \pm \text { SD), Median, No. }\end{array}$ & $(344.92 \pm 172.20), 305.00,62$ & $(319.52 \pm 129.73), 327.00,112$ & $(328.57 \pm 146.30), 317.50,174$ & 0.757 \\
\hline $\begin{array}{l}\text { At } 2 \text { Years' Duration } \\
\text { (Mean } \pm \text { SD), Median, No. }\end{array}$ & $(368.42 \pm 187.55), 335.00,45$ & $(315.82 \pm 123.84), 327.00,76$ & $(342.07 \pm 153.81), 330.00,121$ & 0.084 \\
\hline $\begin{array}{l}\text { At } 2.5 \text { Years' Duration } \\
\text { (Mean } \pm \text { SD), Median, No. }\end{array}$ & $(433.94 \pm 259.33), 385.00,18$ & 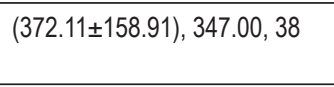 & $(391.98 \pm 196.53), 347.00,56$ & 0.611 \\
\hline $\begin{array}{l}\text { At } 3 \text { Years' Duration } \\
\text { (Mean } \pm \text { SD), Median, No. }\end{array}$ & $(448.00 \pm 226.75), 425.00,8$ & $(359.79 \pm 114.68), 376.00,28$ & $(379.39 \pm 147.69), 376.50,36$ & 0.446 \\
\hline $\begin{array}{l}\text { At } 3.5 \text { Years' Duration } \\
\text { (Mean } \pm \text { SD), Median, No. }\end{array}$ & $(474.29 \pm 255.59), 617.00,7$ & $(385.39 \pm 121.13), 384.00,18$ & $(410.28 \pm 168.47), 387.00,25$ & 0.363 \\
\hline \multicolumn{5}{|c|}{$\begin{array}{l}\text { P value was calculated by Mann-Whitney Test (non-parametric test) } \\
\text { * Significant value } \\
\text { **After one year of having taken ART, the mean CD4 count became more in TB co-infected individuals compared to those who had no TB co- } \\
\text { infection. Then subsequently the mean CD4 count was always at higher level among those who had TB compared to those who hadn't. }\end{array}$} \\
\hline
\end{tabular}


Table 4. Change and comparison of $\mathrm{CD}_{4}$ count in HIV infected individuals six monthly, among those who were under ART and those who weren't, during the course of ART for a period of three and half years. $(n=313)$

\begin{tabular}{|c|c|c|c|c|}
\hline \multirow{2}{*}{$\begin{array}{l}C D_{4} \text { Count } \\
\text { (Six Monthly) }\end{array}$} & \multicolumn{2}{|c|}{ Receiving ART } & \multirow[t]{2}{*}{ Total } & \multirow{2}{*}{$\begin{array}{c}P \\
\text { value }\end{array}$} \\
\hline & Yes & No & & \\
\hline $\begin{array}{l}\text { Just Before Starting ART } \\
\text { (Mean } \pm \text { SD), Median, No. }\end{array}$ & $(180.16 \pm 98.97), 168.00,295$ & $(447.78 \pm 166.05), 425.00,18$ & $(195.55 \pm 120.94), 172.00,313$ & $<0.001^{*}$ \\
\hline $\begin{array}{l}\text { At } 6 \text { Months' Duration } \\
\text { (Mean } \pm \text { SD), Median, No. }\end{array}$ & $(268.85 \pm 120.68), 255.00,286$ & $(409.00 \pm 86.08), 431.50,4$ & $(270.79 \pm 121.27), 255.50,290$ & $0.013^{*}$ \\
\hline $\begin{array}{l}\text { At } 1 \text { Year's Duration } \\
\text { (Mean } \pm \text { SD), Median, No. }\end{array}$ & $(300.77 \pm 143.20), 291.50,226$ & $(473.33 \pm 144.68), 400.00,3$ & $(303.03 \pm 144.24), 293.00,229$ & $0.026^{*}$ \\
\hline $\begin{array}{l}\text { At } 1.5 \text { Years' Duration } \\
\text { (Mean } \pm \text { SD), Median, No. }\end{array}$ & $(328.21 \pm 146.65), 315.00,173$ & - & - & - \\
\hline $\begin{array}{l}\text { At } 2 \text { Years' Duration } \\
\text { (Mean } \pm \text { SD), Median, No. }\end{array}$ & $(342.07 \pm 153.81), 330.00,121$ & - & - & - \\
\hline $\begin{array}{l}\text { At } 2.5 \text { Years' Duration } \\
\text { (Mean } \pm \text { SD), Median, No. }\end{array}$ & $(391.98 \pm 196.53), 347.00,56$ & - & - & - \\
\hline $\begin{array}{l}\text { At } 3 \text { Years' Duration } \\
\text { (Mean } \pm \text { SD), Median, No. }\end{array}$ & ${ }^{* *}(379.39 \pm 147.69), 376.50,36$ & - & - & - \\
\hline $\begin{array}{l}\text { At } 3.5 \text { Years' Duration } \\
\text { (Mean } \pm \text { SD), Median, No. }\end{array}$ & $(410.28 \pm 168.47), 387.00,25$ & - & - & - \\
\hline \multicolumn{5}{|c|}{$\begin{array}{l}\text { P value was calculated by Mann-Whitney Test (Non-parametric test) } \\
{ }^{*} \text { Significant value }\end{array}$} \\
\hline
\end{tabular}

\section{DISCUSSION}

The present study estimated the prevalence of TB co-infection among HIV positive individuals to be $36.1 \%$ in context Nepal which is consistent with worldwide statistics. ${ }^{1}$ There was significant association of TB co-infection among male compared to females $(\mathrm{OR}=1.95, \mathrm{Cl}=1.06-2.37$, $\mathrm{P}=0.021$ ). Among $\mathrm{TB}$ co-infected cases, fever was the commonest clinical feature, followed by weight loss and cough. A night sweat, which was considered as one of the constitutional symptoms didn't have dominant figure in this study.

Other symptoms among the cases were chronic diarrhea (31\%), headache $(29.2 \%)$, easy fatigue $(21.2 \%)$ and night sweats (4.4\%). However only fever, weight loss and cough were the significant symptom associated with TB co-infection. The clinical presentation of TB in HIV infection is affected by the degree of underlying immune suppression. ${ }^{5}$ Our study is consistent with this fact because we found that the mean $\mathrm{CD}_{4}$ counts of the patients co-infected with TB being much less than in those who were not. Of all symptoms, weight loss can be of utmost important. Studies have repeatedly documented that the existence and magnitude of weight loss predict morbidity and mortality. ${ }^{18,19}$ Correlations have been established between high HIV viral load, low CD4 cell counts, and weight loss. In HAART experienced patients with suppressed plasma viral load, weight loss has been attributed to the persistence of HIV in peripheral blood monocytes and macrophages. The persistence of HIV leads to excessive cytokine activation and dysregulation, and this in turn triggers various metabolic abnormalities that lead to weight loss such as increase in resting energy expenditure, proteolysis, and hypercatabolism. ${ }^{17} \mathrm{~A}$ study reported that as little as $5 \%$ of weight loss over 4 months was associated with decreased survival. ${ }^{20}$

We also found that the majority of the patients lived with family .i.e. the major bulk of HIV infected patients had good support from the family as $61.7 \%$ lived with their family. Had there been no co-operation from the family, they would not be staying along with the family members. Stay in rehabilitation center counted for second largest population $(21.4 \%)$. It was due to the reason that they wanted to live with individuals having same disease so that they could share their feelings and learn more about the disease. Also, a good number of populations lived alone (16.3\%) which may be indicative of lack of social support. Environmental 
social determinants, such as housing conditions, social networks, and social support, are also key drivers for HIVIAIDS, viral hepatitis, STDs, and TB. Kidder et al. conducted a study among housed and homeless individuals with HIVIAIDS and found that homeless people with HIVIAIDS had poorer health status, were less adherent to medication regimens, and were more likely to be uninsured and to have been hospitalized. ${ }^{21}$

There is effect of tuberculosis on mortality in HIV positive people. A Meta-Analysis shows that people living with HIV (PLWH) with TB face an approximately two times higher risk of death from all causes compared to PLWH without TB. The increased hazard of mortality implies that PLWH with TB die earlier compared to PLWH without TB. ${ }^{22}$ In our study more than one third (36.1\%) persons were co-infected with TB.

Our study revealed that nearly two third (64.6\%) of TB infected patients had pulmonary TB followed by gland TB $(25.7 \%)$ and spinal TB $(5.3 \%)$. This supports that prime concern of co-infection of TB in HIV positive individuals is that of pulmonary TB followed by gland TB. At CD4+ cell counts greater than $350 / \mu \mathrm{L}$, TB disease is most often limited to the lungs, histopathologic results are similar to those in HIV-seronegative patients (i.e., granuloma with or without caseation), and extrapulmonary involvement, when present, usually is nodal or pleural (Burman and Jones, Semin Respir Infect, 2003). In advanced HIV infection, pulmonary involvement is still the most common TB presentation; however, extra-pulmonary involvement is observed in approximately $70 \%$ of patients with CD4+ cell counts less than 100/ $\mu \mathrm{L}$, and up to $50 \%$ of those with CD4+ cell counts greater than $50 / \mu \mathrm{L}$ will have positive TB blood cultures. $^{5}$

With proper treatment, a person with infectious tuberculosis very quickly becomes non- infectious - probably most often in less than two weeks and so can no longer transmit infection to others. ${ }^{7}$ Highly active antiretroviral therapy (HAART) improves the immune function and decreases morbidity, mortality and opportunistic infections in HIV-infected patients. HAART improves immune function by suppressing HIV viral replication and increasing CD4+ T-cell counts. ${ }^{23}$
With respect to our study- before starting ART, the average CD4 count was found to be significantly less among TB-HIV co-infected patients compared to those who didn't have TB co-infection. Similarly, after six months, the mean CD4 count was significantly associated among the two groups. After one year of having taken ART, the mean CD4 count became more in TB co-infected individuals compared to those who had no TB co-infection. Then subsequently the mean CD4 count was always at higher level among those who had TB compared to those who hadn't.

The risk of TB following M. tuberculosis infection is determined mainly by the individual's immune status (and hence HIV infection is a potent risk factor for tuberculosis). ${ }^{6}$ It was found that the mean $\mathrm{CD}_{4}$ count was in increasing pattern without any turn down for three and half years among TB coinfected individuals, but the group which were TB free had fluctuating mean CD4 count. This shows that there is marked increase in CD4 count in TB co-infected individuals despite lower initial CD4 count before starting ART. But after three and half years the variation is somewhat similar. Studies of the kinetics of CD4+ count response post-HAART indicate that the $\mathrm{CD} 4+$ count increases rapidly during the first 3-6 months, in part due to release of memory T-cells from lymphoid tissue, and then increases slowly during the next 3-4 years, reflecting reconstitution of the immune system. The magnitude of CD4+ recovery may depend on a variety of factors, including maintenance of virologic suppression, age, and $\mathrm{CD} 4+$ count at HAART initiation. ${ }^{11}$

There are no validated markers to differentiate those who will have a more robust CD4 response to ARV from those who will not. ${ }^{24}$ Antiretroviral drug concentrations are among the most important determinants of clinical response to a drug accounting for both toxicity and efficacy. ${ }^{25}$ We also tried to see pattern of change of mean $\mathrm{CD}_{4}$ count among different type of TB co-infection. Those people who had pulmonary TB, had mean CD4 count of 157.86 just before starting ART compared to mean CD4 count of 214.21 in the individuals who had TB of gland and 127.17 in the individuals who had TB of spine. The mean $\mathrm{CD}_{4}$ count of 157.86 for pulmonary TB is quite low as compared to other similar studies. It could have been so because there 
was also hepatitis infection among the volunteers of the study. Among TB co-infected individuals, $6.2 \%$ had HBV alone, 38.9\% had HCV alone and $2.7 \%$ had both HBV and HCV infection. Another explanation could be that TB facilitates HIV viral replication to a greater extent in the earlier stages of HIV infection than during advanced illness, when viral replication is already at its peak. ${ }^{26}$ We found that the mean CD4 count was in rising pattern without any decline for three and half years among the population with pulmonary $\mathrm{TB}$, but the ones having TB of gland also had rising pattern of mean CD4 count but only for two years. Then the mean CD4 count had falling pattern till three and half years. The mass of people having TB of spine had fluctuating pattern of mean CD4 count as shown in figure 3.

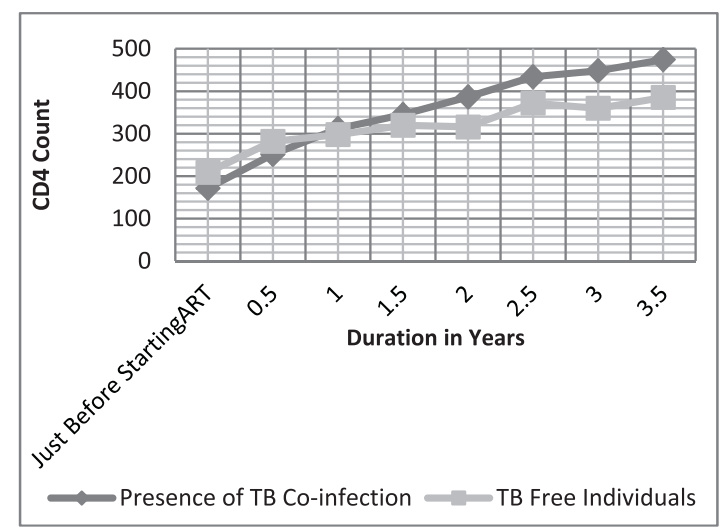

Figure 3. Change and comparison of mean $\mathrm{CD}_{4}$ cell count in HIV infected individuals six monthly, among those who had TB co-infection and those who hadn't, during the course of ART for a period of three and half years. $(n=313)$.

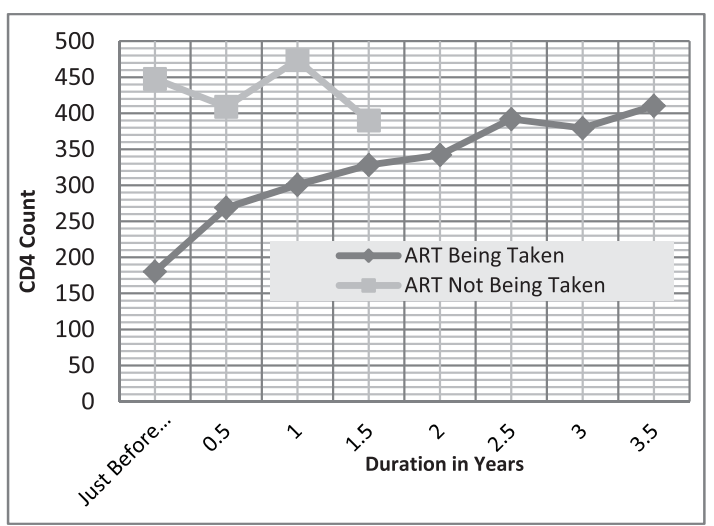

Figure 4. Change and comparison of mean $\mathrm{CD}_{4}$ cell count in HIV infected individuals six monthly, among those who were taking ART and those who weren't taking ART, during the course of ART for a period of three and half years. $(n=313)$.
The question of whether those initiating HAART will continue to increase their CD4+ count after 4-5 years or will plateau has been debated in the literature, and remains unclear. Some studies have suggested that normalization of CD4+ counts in HIV-infected persons can be achieved if viral suppression with HAART can be maintained for a sufficiently long period of time. ${ }^{11}$ Several factors such as age, ethnicity, body weight and patients' immune status may influence antiretroviral drug concentrations. ${ }^{25}$ In our study, those who were taking ART had mean CD4 count of 180.16 just before starting ART compared to mean CD4 count of 447.78 in the individuals who were not taking ART. We found that the mean CD4 count was in increasing pattern without any decline for two and half years among the population taking ART whereby the mean CD4 count was 391.98. But in succeeding six months' duration, the mean CD4 count decreased to 379.39. In subsequent six month the mean CD4 count increased to 410.28. The mass not taking ART had falling pattern of mean CD4 count for one and half year (Table 3). In one study, after $>5$ years on HAART, patients with viral suppression who started at $<200$ cells/ $\mathrm{mm} 3$ had an adjusted annual increase of 32 cells/ mm3, attaining an average CD4+ count of 497 cells/mm3. Another study statistically estimating the CD4+ trajectory concluded that those starting HAART at <200 CD4+ cells who remained on therapy would continue to increase through 7 years, although $25 \%$ still had $<350$ cells at 7 years. One small study of 16 patients followed for up to 10 years with strict viral control based on HIV RNA detection using ultrasensitive techniques showed continued positive increases in CD4 + counts, although this study represented a small group of highly selected patients. ${ }^{11}$

On the other hand, other studies report that the average CD4+ count may level off after 4-6 years following HAART initiation, even among patients with viral suppression. Given this leveling off, many patients who start at lower CD4+ counts, even after years on HAART with early CD4+ increases, may fail to reach a normal $\mathrm{CD}_{4}$ + threshold. In one study of those with sustained viral suppression who started HAART at $<200 \mathrm{CD} 4+$ cells $/ \mathrm{mm} 3$, after 6 years only $42 \%$ had $>500 \mathrm{CD} 4+$ cells $/ \mathrm{mm} 3$, and only $12 \%$ had $>750$ cells $/ \mathrm{mm} 3$. In another study, $44 \%$ of those starting therapy with a CD4+ count $<100$ cells $/ \mathrm{mm} 3$ and $25 \%$ of those starting HAART 
with a CD4+ count of 100-200 cells were unable to achieve a CD4+ cell count $>500$ cells $/ \mathrm{mm} 3$ over a mean follow-up of seven years, and many did not reach this threshold by year $10 .{ }^{11}$

Antiretroviral therapy improves survival in HIVpositive patients. In addition, antiretroviral therapy reduces TB rates by up to $90 \%$ at an individual level, by $60 \%$ at a population level and it reduces TB recurrence rates by $50 \%$. ART should be initiated for all people living with HIV with active TB disease irrespective of CD4 cell count. TB treatment should be started first, followed by ART as soon as possible and within the first 8 weeks of starting TB treatment. ${ }^{27}$

Despite several explanations, the most important aspect is the survival the HIV infected individuals. Death rates in HIV-positive individuals remain elevated compared to those in the general population and it is believed that HIV may play a role in the development of several serious nonAIDS conditions. Thus, combination ART may have a greater positive impact on the health of HIV-positive individuals than anticipated, which may now justify its earlier use. ${ }^{28}$

The dramatic scale-up of ART in resource-limited settings has brought not only TB treatment but also prevention of TB in HIV-infected persons to the forefront. TB prevention strategies with known efficacy include rapid identification and treatment of active TB cases (in source patients), infection-control measures to reduce nosocomial transmission of TB and ART to reduce the incidence of TB among HIV-infected patients. Research priorities in TB prevention center on adapting and improving these known strategies for HIV infection in resource-limited settings. ${ }^{9}$

\section{CONCLUSION}

TB and HIV co-infection is an emerging medical issue in Nepal. The prevalence of TB coinfection among HIV cases is found to be $36.1 \%$. Consideration of TB need to be made while caring patients with HIV infection and vice versa. Timely given ART can be of utmost significance so it should be initiated when CD4 cell count falls below the cut off value. Preventive, promotive and curative aspects of TB and HIV should be undertaken hand in hand so that both of these entities are addressed simultaneously.

\section{ACKNOWLEDGEMENTS}

Had there been no support from SPARSA Nepal (Kathmandu), Sukraraj Tropical and Infectious Disease Hospital (Teku, Kathmandu) and BPKIHS, Dharan; the study could not have been completed. A sincere gratitude to all the HIV infected individuals who kindly co-operated for the study despite ill health. Due concern is expressed to all the crew members of the study group. Special thanks to Prof. Suman Rijal and Dr. Naveen Pandey from Department of Internal Medicine, BPKIHS for kind co-operation.

\section{REFERENCES}

1. Retrieved from http://hinari-gw.who.int/ whalecomwww.ncbi.nlm.nih.gov / whalecom0/ pmc / articles / PMC2873981 / pdf/pone.0010736.pdf on $8^{\text {th }}$ February, 2011.

2. Piggott DA and Karakousis PC. Review Article Timing of Antiretroviral Therapy for HIV in the Setting of TB Treatment. Hindawi Publishing Corporation Clinical and Developmental Immunology Volume 2011, Article ID 103917

3. Reitz C, Coovadia A, Ko S, Meyers T, Strehlau R, et al. Initial Response to Protease-Inhibitor-Based Antiretroviral Therapy among Children less than Two Years of Age in South Africa: Effect of Cotreatment for Tuberculosis. J Infect Dis. 2010 April 15;201:1121-31.

4. Annual report, Department of Health Services 2066/67(2009/2010). Government of Nepal, Ministry of Health and Population, Department of Health Services, Kathmandu. P-4.

5. Perspective Current Issues in the Diagnosis and Management of Tuberculosis and HIV Coinfection in the United States, Managing Tuberculosis in HIV Infection, Volume 18 Issue 4 October/ November 2010:143-48.

6. Heysell SK, Thomas TA, Gandhi NR, Moll AP, Eksteen FJ, et al. Blood cultures for the diagnosis of multidrug resistant and extensively drugresistant tuberculosis among HIV-infected patients from rural South Africa: a cross-sectional study. BMC Infectious Diseases 2010;10:344. http: // www.biomedcentral.com / 1471-2334 / 10/344 
7. Maher D. Re-thinking global health sector efforts for HIV and tuberculosis epidemic control: promoting integration of programme activities within a strengthened health system. BMC Public Health 2010;10:394. http://www.biomedcentral. com/1471-2458/10/394

8. Date AA, Vitoria M, Granich R, Banda M, Foxb MY, et al. Implementation of co-trimoxazole prophylaxis and isoniazid preventive therapy for people living with HIV. Bull World Health Organ 2010;88:25359.

9. Chamie G, Luetkemeyer A, Charlebois E, and Havlir DV. Tuberculosis as Part of the Natural History of HIV Infection in Developing Countries. Clin Infect Dis. 2010 May 15;50(Suppl 3).

10. Retrieved from http://hinari- gw.who.int/ whalecomwww.ncbi.nlm.nih.gov/ whalecom0 / pmc / articles / PMC2915483 / pdf / Dtsch_Arztebl_Int107-0507.pdf on $8^{\text {th }}$ February, 2011.

11. Retrieved from http://hinari-gw.who.int / whalecomwww.ncbi.nlm.nih.gov / whalecom0 / pubmed / 21244701 on 8th February, 2011.

12. Kuniholm MH, Mark J, Aladashvili M, Shubladze N, Khechinashvili G, et al. Risk factors and algorithms to identify hepatitis $C$, hepatitis $B$, and HIV among Georgian tuberculosis patients. Int J Infect Dis. 2008; 12:51-56.

13. Graham Douglas, Fiona Nicol, Colin Robertson. Macleod's Clinical Examination; Eleventh Edition: 58.

14. Helen ML, Lim SG, Chew SK. International Conference on AIDS. Int Conf AIDS. 1996;11:107.

15. Nicholas A. Boon, Nicki R. Colledge, Brian R. Walker, John A. A. Hunter. Davidson's Principles \& Practice of Medicine; 20 ${ }^{\text {th }}$ Edition: 295.

16. Sharma SK, Dhooria S, Prasad KT, George N, Ranjan S, et al. Outcomes of antiretroviral therapy in a northern Indian urban clinic. Bull World Health Organ 2010;88:222-26.

17. Ogoina D, Obiako RO, and Muktar HM. HIV Wasting Syndrome in a Nigerian Failing Antiretroviral Therapy: A Case Report and Review of the Literature. Hindawi Publishing Corporation Case Reports in Medicine Volume 2010.

18. Chlebowski RT, Grosvenor MB, Bernhard NH, et al. Nutritional status, gastrointestinal dysfunction, and survival in patients with AIDS. Am J Gastroenterol 1989;84:1288-93.
19. Palenicek JP, Graaham NM, He YD, et al. Weight loss prior to clinical AIDS as a predictor of survival. Multicenter AIDS Cohort Study Investigators. J Acquir Immune Defic Syndr Hum Retrovirol 1995;10:366-73.

20. Wheeler DA, Gibert CL, Launer CA, et al. Weight loss as a predictor of survival and disease progression of HIV infection. J Acquir Immune Defic Syndr Hum Retrovirol 1998;18:80-5.

21. Sharpe TT, Harrison KMD, Dean HD, et al. Summary of CDC Consultation to Address Social Determinants of Health for Prevention of Disparities in HIVIAIDS, Viral Hepatitis, Sexually Transmitted Diseases, and Tuberculosis. Public Health Reports 2010 Supplement 4;125:11-15.

22. Retrieved from http://hinari-gw.who.int/ whalecomwww.ncbi.nlm.nih.gov/whalecom0/ pubmed/21209936 on 2nd February, 2011.

23. Huruy K, Kassu A, Mulu A, Wondie Y. Immune restoration disease and changes in CD4+ T-cell count in HIV- infected patients during highly active antiretroviral therapy at Zewditu memorial hospital, Addis Ababa, Ethiopia. AIDS Research and Therapy 2010;7:46.

24. Schacker TW, Bosch RJ, Bennett K, Pollard R, Robbins GK, et al. Measurement of Naive CD4 Cells Reliably Predicts Potential for Immune Reconstitution in HIV. J Acquir Immune Defic Syndr. 2010;54:59-62.

25. Kumar AKH, Ramachandran G, Rajasekaran S, Padmapriyadarsini C, NarendranG, et al. Pharmacokinetics of lamivudine \& stavudine in generic fixed-dose combinations in HIV-1 infected adults in India. Indian J Med Res. 2009;130:45157.

26. Sharma SK, Dhooria S, Prasad KT, George N, Ranjan $\mathrm{S}$, et al. Outcomes of antiretroviral therapy in a northern Indian urban clinic. Bull World Health Organ 2010;88:222-26.

27. Treatment of Tuberculosis: Guidelines - 4th edition, WHO, 2009.

28. Sabin CA. When should antiretroviral therapy be started in HIV-positive persons. F1000 Medicine Reports 2010;2:81. 